Article

\title{
Synthesis and Antimicrobial Characterization of Half-Calycanthaceous Alkaloid Derivatives
}

\author{
Shaojun Zheng ${ }^{1,2,3}$, Xinping Zhou ${ }^{2}$, Shixun $\mathrm{Xu}^{2}{ }^{2}$, Rui Zhu ${ }^{1}$, Hongjin Bai ${ }^{2, *}$ and Jiwen Zhang ${ }^{2,3, *}$ \\ 1 School of Environmental and Chemical Engineering, Jiangsu University of Science and Technology, \\ Zhenjiang 212003, Jiangsu, China; sz281cam@just.edu.cn (S.Z.); zhurui991314@163.com (R.Z.) \\ 2 Key Laboratory of Protection \& Utilization of Biological Resources in Tarim Basin of Xinjiang Production \\ and Construction Corps/College of Life Sciences, Tarim University, Alar 843300, Xinjiang, China; \\ zhouzhouxinping@163.com (X.Z.); xsx_89@163.com (S.X.) \\ 3 Key Laboratory of Botanical Pesticide R \& D in Shaanxi Province, Yangling 712100, Shaanxi, China \\ * Correspondence: bhj67@163.com (H.B.); nwzjw@nwsuaf.edu.cn (J.Z.); \\ Tel.: +86-997-4681-612 (H.B.); +86-29-8709-3987 (J.Z.)
}

Academic Editor: Kamal Kumar

Received: 3 July 2016; Accepted: 6 September 2016; Published: 9 September 2016

\begin{abstract}
A total of 29 novel tetrahydropyrroloindol-based calycanthaceous alkaloid derivatives were synthesized from indole-3-acetonitrile in good yields. The synthesized compounds were evaluated against nine strains of bacteria and a wide range of plant pathogen fungi. Bioassay results revealed that majority of the compounds displayed similar or higher in vitro antimicrobial activities than the positive control. The biological activities also indicated that substituents at $R_{4}$ and $R_{5}$ significantly affect the activities. Notably, compound $\mathrm{c} 4$ was found to be most active among the tested calycanthaceous analogues and might be a novel potential leading compound for further development as an antifungal agent. The results could pave the way for further design and structural modification of calycanthaceous alkaloids as antimicrobial agents.
\end{abstract}

Keywords: calycanthaceous alkaloids; synthesis; biological activity; agrochemicals; SAR

\section{Introduction}

As a part of conventional agriculture, agrochemicals play an important role in the protection of vegetable and cereal crops. However, the unrestricted usage of highly toxic agrochemicals over the past several decades had caused negative effects on environment and poisoned non-targeted species. Therefore, to reduce the negative impacts of agrochemicals, new compounds with high efficacy against target species are desired. Natural-product-based libraries provide a rich source for new agrochemical discovery [1-4]. Calycanthaceous alkaloids [5,6] (Figure 1), mainly distributed in China, North America and Australia [7,8], are an important class of alkaloids that can be isolated from the roots, leaves, flowers, and fruits of Chimonanthus praecox [9], and have demonstrated widespread biological activities such as anticonvulsant, antifungal, antiviral, analgesic, antitumor, and inhibition of melanogenesis properties [10-13]. Due to their broad spectrum of biological properties, a number of studies towards the synthesis and antimicrobial activity of calycanthaceous alkaloids have been reported [13-25]. However, the core structure of calycanthaceous alkaloids is underexplored. Therefore, we focused on the structural optimization of tetrahydropyrroloindole. It was hoped that a leading compound could be identified for the discovery of novel antimicrobial agents. Herein, a series of novel calycanthaceous alkaloids analogs were designed and synthesized using indole-3-acetonitrile as the starting material.

To the best of our knowledge, the antimicrobial activities of the synthetic derivatives are reported herein for the first time. 


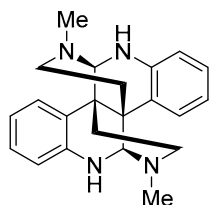

(+)-calycanthine (1)

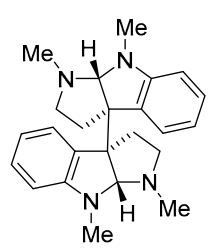

(-)-folicanthine(2)

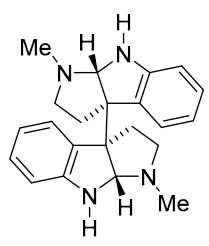

(-)-chimonanthine(3)

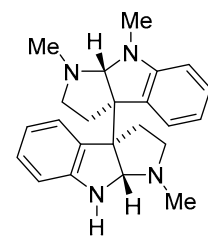

(-)-calycanthidine $(4)$

Figure 1. Structures of calycanthaceous alkaloids.

\section{Results and Discussion}

\subsection{Design and Synthesis of Calycanthaceous Alkaloids Analogues}

The synthetic route is outlined in Scheme 1. Intermediates 1-8 were synthesized according to the corresponding references and their spectral data were consistent with literature values [26-28]. The analogs of calycanthaceous alkaloids were synthesized using indole-3-acetonitrile as the starting material via acylation at the N3 position. Twenty nine derivatives were synthesized and characterized by ${ }^{1} \mathrm{H}-\mathrm{NMR}$, and ${ }^{13} \mathrm{C}-\mathrm{NMR}$ spectroscopy and ESI-MS.

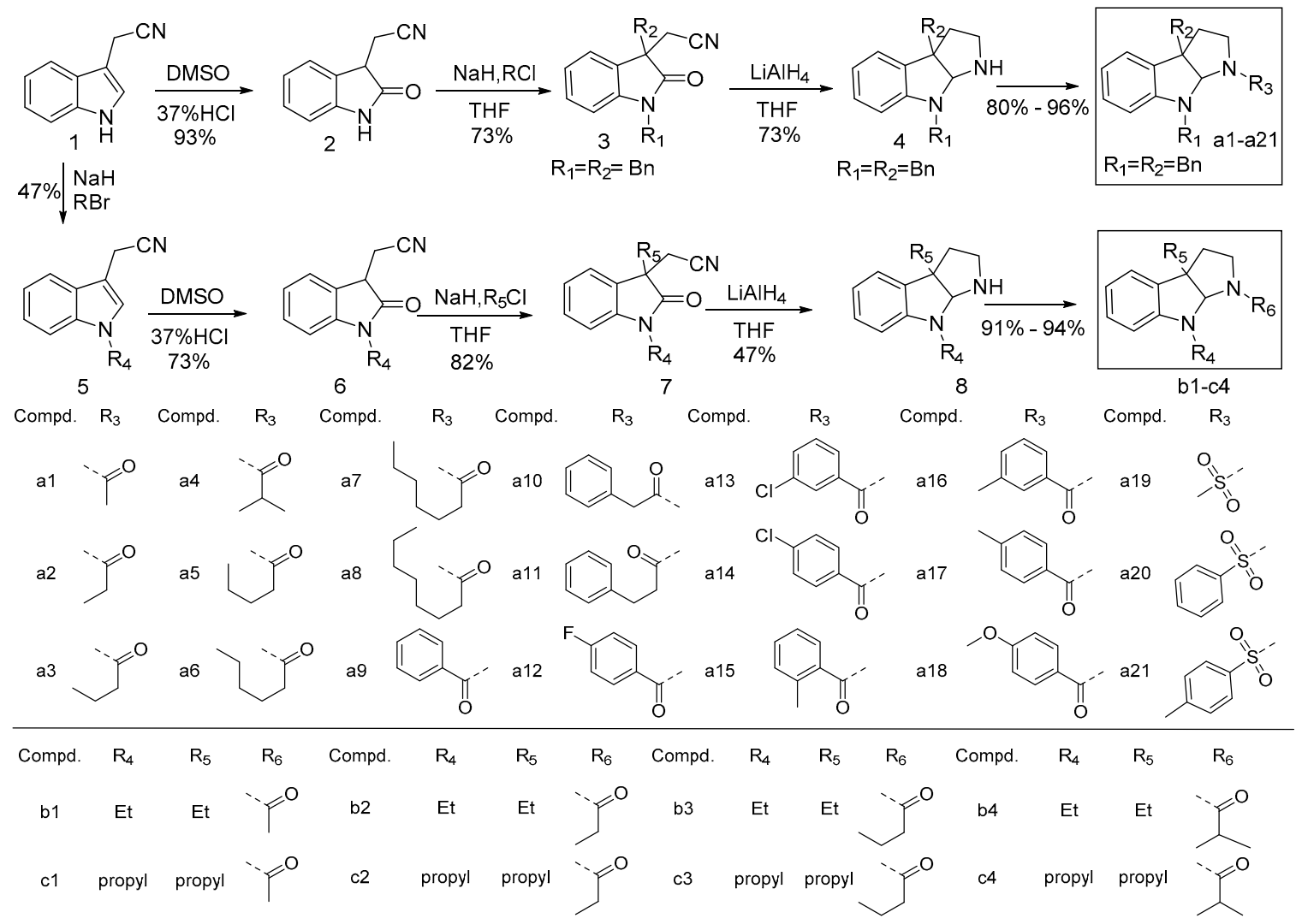

Scheme 1. Synthetic route to the title compounds a1-a21 and b1-c4.

\subsection{Antimicrobial Acitivity}

Antibacterial results are shown in Table 1. MIC and MBC values were determined using the microdilution method, with gentamicin and streptomycin as positive controls to evaluate the biological activities of analogues against Gram-positive bacteria (B. cereus, S. aureus, and S. epidermidis). 
Table 1. Antibacterial activity of calycanthaceous alkaloids derivatives against B. cereus, S. aureus, and S. epidermidis.

\begin{tabular}{|c|c|c|c|c|c|c|}
\hline \multirow{2}{*}{ Compounds } & \multicolumn{3}{|c|}{ MIC $\mu \mathrm{g} / \mathrm{mL}$} & \multicolumn{3}{|c|}{$\mathrm{MBC} \mu \mathrm{g} / \mathrm{mL}$} \\
\hline & B. cereus & S. aureus & S. epidermidis & B. cereus & S. aureus & S. epidermidis \\
\hline a1 & - & 256 & 62.5 & - & - & 125 \\
\hline a2 & - & 256 & 62.5 & - & - & 125 \\
\hline a3 & 125 & - & - & 256 & - & - \\
\hline a4 & - & - & 62.5 & - & - & 125 \\
\hline a5 & - & - & - & - & - & - \\
\hline a6 & 256 & - & - & - & - & - \\
\hline a7 & 31.25 & 256 & 62.5 & 62.5 & - & 125 \\
\hline a8 & 62.5 & 256 & 125 & 125 & - & 256 \\
\hline a9 & 125 & - & - & 256 & - & - \\
\hline a10 & 125 & - & - & 256 & - & - \\
\hline a11 & 31.25 & 125 & 62.5 & 62.5 & 256 & 125 \\
\hline a12 & 15.63 & - & - & 31.25 & - & - \\
\hline a13 & - & - & - & - & - & - \\
\hline a14 & 256 & - & - & - & - & - \\
\hline a15 & 256 & - & - & - & - & - \\
\hline a16 & 62.5 & - & - & 125 & - & - \\
\hline a17 & - & - & - & - & - & - \\
\hline a18 & - & - & - & - & - & - \\
\hline a19 & - & 256 & 62.5 & - & - & 125 \\
\hline a20 & 125 & 256 & 125 & 256 & - & 256 \\
\hline a21 & - & - & - & - & - & - \\
\hline b1 & 62.5 & 125 & 125 & 125 & 256 & 256 \\
\hline b2 & 31.25 & 125 & 125 & 62.5 & 256 & 256 \\
\hline b3 & 7.81 & 125 & 125 & 15.63 & 256 & 256 \\
\hline b4 & 31.25 & 256 & 125 & 62.5 & - & 256 \\
\hline c1 & 62.5 & 125 & 62.5 & 125 & 256 & 125 \\
\hline c2 & 125 & 125 & 62.5 & 256 & 256 & 125 \\
\hline c3 & 62.5 & 125 & 125 & 125 & 256 & 256 \\
\hline c4 & 62.5 & 31.25 & 31.25 & 125 & 62.5 & 62.5 \\
\hline gentamicin & - & 62.5 & 15.63 & - & 125 & 31.25 \\
\hline streptomycin & 1.96 & 15.63 & 31.25 & 3.9 & 31.25 & 62.5 \\
\hline
\end{tabular}

Note: The gentamicin and streptomycin were used as the positive controls; " $-"$ means no inhibition effect. MIC: Minimal Inhibitory Concentration; MBC: Minimum Bactericidal Concentration.

Tables 1 and 2 show which of the synthesized compounds exhibited potent in vitro antimicrobial activities against $B$. cereus, $S$. aureus, and $S$. epidermidis. Compounds a3, a7-a12, a16, a20, b1-b4 and $\mathbf{c 1 - c 4}$ showed higher degrees of activity against $B$. cereus than gentamicin, with $\mathbf{b} \mathbf{3}$ and $\mathbf{a 1 2}$ being the most effective, with MIC values of $7.81 \mu \mathrm{g} \cdot \mathrm{mL}^{-1}$ and $15.63 \mu \mathrm{g} \cdot \mathrm{mL}^{-1}$, respectively. Compound a4 showed comparable control efficacy against $S$. epidermidis to that of gentamicin. Noticeably, compound c4 revealed potent activity against B. cereus, S. aureus, and S. epidermidis, with MIC values of $62.5 \mu \mathrm{g} \cdot \mathrm{mL}^{-1}, 31.25 \mu \mathrm{g} \cdot \mathrm{mL}^{-1}$, and $31.25 \mu \mathrm{g} \cdot \mathrm{mL}^{-1}$, respectively. 
Table 2. Antibacterial activity of calycanthaceous alkaloids derivatives against E. coli, S. typhimurium, S. flexneri, Escherichia sp., P. aeruginosa, and R. solanacearum.

\begin{tabular}{|c|c|c|c|c|c|c|c|c|c|c|c|c|}
\hline \multirow{2}{*}{ Compounds } & \multicolumn{6}{|c|}{ MIC $\mu \mathrm{g} / \mathrm{mL}$} & \multicolumn{6}{|c|}{ MBC $\mu \mathrm{g} / \mathrm{mL}$} \\
\hline & E.c. & S.t. & S.f. & E.s. & P.a. & R.s. & E.c. & S.t. & S.f. & E.s. & P.a. & R.s. \\
\hline a1 & 125 & 31.25 & 62.5 & 62.5 & 256 & 62.5 & 256 & 62.5 & 125 & 125 & - & 125 \\
\hline a2 & 125 & 125 & 125 & 125 & 125 & - & 256 & 256 & 256 & 256 & 250 & - \\
\hline a3 & - & - & - & - & 125 & 125 & - & - & - & - & 250 & 256 \\
\hline a4 & - & 125 & 125 & - & 125 & 7.81 & - & 256 & 256 & - & 250 & 15.63 \\
\hline a5 & - & - & - & - & 125 & 125 & - & - & - & - & 250 & 256 \\
\hline a6 & - & - & - & - & 62.5 & 256 & - & - & - & - & 125 & - \\
\hline a7 & 62.5 & 125 & - & 125 & 62.5 & 7.81 & 125 & 256 & - & 256 & 125 & 15.63 \\
\hline a8 & 62.5 & 125 & 125 & 125 & 62.5 & 31.25 & 125 & 256 & 256 & 256 & 125 & 62.5 \\
\hline a9 & - & - & - & - & 125 & 15.63 & - & - & - & - & 250 & 31.25 \\
\hline a10 & - & - & - & - & 62.5 & 125 & - & - & - & - & 125 & 256 \\
\hline a11 & 62.5 & 125 & 62.5 & 125 & 62.5 & 15.63 & 125 & 256 & 125 & 256 & 125 & 31.25 \\
\hline a12 & - & 125 & 125 & - & 125 & 7.81 & - & 256 & 256 & - & 250 & 15.63 \\
\hline a13 & - & 125 & 125 & - & - & - & - & 256 & 256 & - & - & - \\
\hline a14 & - & 125 & 125 & - & 62.5 & 256 & - & 256 & 256 & - & 125 & - \\
\hline a15 & - & 125 & 125 & - & 125 & 256 & - & 256 & 256 & - & 250 & - \\
\hline a16 & - & 125 & 256 & - & 62.5 & 125 & - & 256 & - & - & 125 & 256 \\
\hline a17 & - & 62.5 & 62.5 & - & 62.5 & 62.5 & - & 125 & 125 & - & 125 & 125 \\
\hline a18 & - & - & - & - & 7.81 & 125 & - & - & - & - & 15.63 & 256 \\
\hline a19 & 62.5 & 125 & 62.5 & 125 & 15.63 & 256 & 125 & 256 & 125 & 256 & 31.25 & - \\
\hline a20 & 62.5 & 125 & - & 125 & 31.25 & 62.5 & 125 & 256 & - & 256 & 62.5 & 125 \\
\hline a21 & - & 125 & 62.5 & - & 125 & - & - & 256 & 125 & - & 250 & - \\
\hline b1 & 62.5 & 125 & 62.5 & - & 125 & 256 & 125 & 256 & 125 & - & 250 & - \\
\hline b2 & 62.5 & 125 & 125 & 125 & 125 & - & 125 & 256 & 256 & 256 & 250 & - \\
\hline b3 & 62.5 & 125 & 62.5 & 62.5 & 62.5 & 125 & 125 & 256 & 125 & 125 & 125 & 265 \\
\hline b4 & 62.5 & - & - & 62.5 & 7.81 & 125 & 125 & - & - & 125 & 15.63 & 256 \\
\hline c1 & 125 & 125 & - & 125 & 31.25 & 125 & 256 & 256 & - & 256 & 62.5 & 256 \\
\hline c2 & 125 & 125 & - & 125 & 15.63 & 125 & 256 & 256 & - & 256 & 31.25 & 256 \\
\hline c3 & 125 & 62.5 & - & 62.5 & 15.63 & 256 & 256 & 125 & - & 125 & 31.25 & - \\
\hline c4 & 31.25 & 62.5 & 31.25 & 16.5 & 62.5 & 1.96 & 62.5 & 125 & 62.5 & 31.25 & 125 & 3.9 \\
\hline gentamicin & 125 & 125 & 256 & 256 & - & - & 256 & 256 & - & - & - & - \\
\hline streptomycin & 125 & 125 & 62.5 & 7.81 & 1.96 & 3.9 & 256 & 256 & 125 & 15.63 & 3.9 & 7.81 \\
\hline
\end{tabular}

As for inhibitory effects of the synthesized compounds against gram-negative bacteria and gram-positive bacteria, 23 compounds exhibited high degrees of activity against E. coli, S. typhimurium, and S. flexneri. 28 compounds showed high degrees of activity against E. coli, P. aeruginosa,

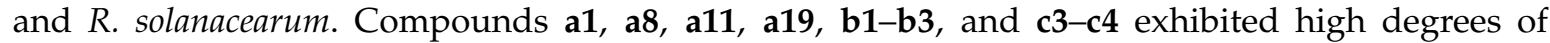
activity against more than two kinds of Gram-negative bacteria than that of gentamicin and streptomycin. Noticeably, compound $\mathbf{c} 4$ showed a broad spectrum and remarkably high activity against E. coli, S. typhimurium, S. flexneri, Escherichia sp., P. aeruginosa, and $R$. solanacearum, with MIC values of $31.25 \mu \mathrm{g} \cdot \mathrm{mL}^{-1}, 62.5 \mu \mathrm{g} \cdot \mathrm{mL}^{-1}, 31.25 \mu \mathrm{g} \cdot \mathrm{mL}^{-1}, 16.5 \mu \mathrm{g} \cdot \mathrm{mL}^{-1}, 62.5 \mu \mathrm{g} \cdot \mathrm{mL}^{-1}$, and $1.96 \mu \mathrm{g} \cdot \mathrm{mL}^{-1}$, respectively.

Inhibitory effects of calycanthaceous alkaloid analogues against a wide range of plant pathogen fungi are listed in Table 3. MIC and MFC were examined with amphotericin B and carbendazim as a positive controlx, to evaluate the activities of the synthesized calycanthaceous alkaloid analogues against P. capsici, V. dahliae, F. oxysperium sp. vasinfectum, C. orbiculare, P. citrinum, Cytospora juglandis, A. sflavu, A. solani, C. lunaia, F. oxysporum, and A. niger. 
Table 3. Inhibitory effect of synthesized compounds against a wide variety of plant pathogen fungi.

\begin{tabular}{|c|c|c|c|c|c|c|c|c|c|c|c|c|c|c|c|c|c|c|c|c|c|c|}
\hline Compounds & \multicolumn{11}{|c|}{\begin{tabular}{lcc}
\multicolumn{3}{c}{ MIC $(\mu \mathrm{g} / \mathrm{mL})$} \\
P.c. & C. $j . \quad$ A.sf.
\end{tabular}} & \multicolumn{11}{|c|}{ MFC $(\mu \mathrm{g} / \mathrm{mL})$} \\
\hline a1 & 31.25 & - & 256 & 125 & - & 125 & 256 & 256 & - & - & 62.5 & 62.5 & - & - & 256 & - & 256 & - & - & - & - & 125 \\
\hline a2 & 256 & - & 256 & 125 & - & 62.5 & 256 & - & - & 256 & - & - & - & - & 256 & - & 125 & - & - & - & - & - \\
\hline a3 & 256 & - & - & - & - & - & 256 & 256 & 62.5 & 125 & 256 & - & - & - & - & - & - & - & - & 125 & 256 & - \\
\hline a6 & - & - & 256 & - & - & - & - & - & - & 125 & 125 & - & - & - & - & - & - & - & - & - & 256 & 256 \\
\hline a7 & - & 256 & 256 & - & - & 125 & - & 256 & 125 & 31.25 & 256 & - & - & - & - & - & 256 & - & - & 256 & 62.5 & - \\
\hline a8 & - & 256 & - & - & - & 256 & - & 125 & 125 & 62.5 & 125 & - & - & - & - & - & - & - & 256 & 256 & 125 & 256 \\
\hline a9 & - & - & - & - & - & - & - & 256 & - & 256 & 256 & - & - & - & - & - & - & - & - & - & - & - \\
\hline a12 & - & - & - & 256 & - & - & - & 256 & - & 62.5 & 125 & - & - & - & - & - & - & - & - & - & 125 & 256 \\
\hline a13 & - & - & - & - & - & - & - & - & - & 256 & 125 & - & - & - & - & - & - & - & - & - & - & 256 \\
\hline a14 & - & - & - & - & - & - & - & - & - & 125 & 256 & - & - & - & - & - & - & - & - & - & 256 & - \\
\hline a15 & - & - & 256 & - & - & - & - & - & - & 62.5 & 256 & - & - & - & - & - & - & - & - & - & 125 & - \\
\hline a16 & - & - & 256 & - & - & 256 & - & - & - & 125 & 125 & - & - & - & - & - & - & - & - & - & 256 & 256 \\
\hline a17 & 256 & - & 125 & 256 & - & - & - & - & - & 256 & 125 & - & - & 256 & - & - & - & - & - & - & - & 256 \\
\hline a18 & 256 & - & 256 & 256 & - & 256 & - & - & 125 & 125 & 62.5 & - & - & - & - & - & - & - & - & 256 & 256 & 125 \\
\hline a19 & 256 & - & 256 & 256 & - & - & - & - & - & 125 & 256 & - & - & - & - & - & - & - & - & - & 256 & - \\
\hline b4 & 125 & - & 256 & 256 & - & - & - & - & - & 125 & 62.5 & 256 & - & - & - & - & - & - & - & - & 256 & 125 \\
\hline c1 & 62.5 & - & - & 125 & 125 & 256 & - & - & 125 & 62.5 & 125 & 125 & - & - & 256 & 256 & - & - & - & & 125 & 256 \\
\hline c2 & 31.25 & - & - & 125 & 125 & - & 62.5 & 256 & 125 & 31.25 & 31.25 & 62.5 & - & - & 256 & 256 & - & 125 & - & 256 & 62.5 & 62.5 \\
\hline c3 & 256 & - & 256 & 256 & 125 & - & 125 & - & - & 256 & 125 & - & - & - & - & 256 & - & 256 & - & - & - & 256 \\
\hline c4 & 31.25 & 62.5 & 256 & 62.5 & 62.5 & - & 15.63 & - & - & 31.25 & 125 & 62.5 & 125 & - & 125 & 125 & - & 31.25 & - & - & 62.5 & 256 \\
\hline A. & 3.9 & 62.5 & 256 & 125 & 15.63 & 256 & 7.81 & - & 7.81 & 125 & 0.97 & 7.81 & 125 & - & 256 & 31.25 & - & 15.63 & - & 15.63 & 256 & 1.93 \\
\hline C. & 1.95 & 256 & 125 & 0.97 & 0.97 & 62.5 & 0.97 & - & - & 7.81 & - & 3.9 & - & 256 & 1.95 & 1.95 & 125 & 1.95 & - & - & 15.63 & - \\
\hline
\end{tabular}

Notes: "-" means no inhibition effect. Amphotericin B and Carbendazim were used as the positive control. P.ca.: P. capsici, V.d.: V. dahlia, F.s.: F. oxysperium sp. vasinfectum, C.o.: C. orbiculare, P.c.: P. citrinum, C.j.: Cytospora juglandis, A.sf:: A. sflavu, A.s.: A. solani, C.l.: C. lunaia, F.o.: F. oxysporum, A.n.: A. niger, A.: Amphotericin B, C.: Carbendazim. MIC: minimal inhibitory concentration; MBC: Minimum Bactericidal Concentration.

It is observed that this series of compounds generally exhibits more effective antimicrobial activity than the positive control. Twenty three compounds exhibited high degrees of activity against P. capsici, V. dahliae, F. oxysperium sp. vasinfectum, and C. orbiculare. Nineteen compounds showed high degrees of activity against $P$. citrinum, $A$. sflavu, and A. solani. Nine of the synthesized compounds manifested high degrees of activity against $C$. lunaia. 27 compounds illustrated high degrees of activity against $F$. oxysporum. Twenty eight compounds manifested high degrees of activity against A. niger. Compounds a11, b2, b3, and $\mathbf{c} 4$ manifested higher degrees of activity against $V$. dahliae than amphotericin B and carbendazim, with $\mathrm{c} 4$ being the most effective with a MIC value of $62.5 \mu \mathrm{g} \cdot \mathrm{mL}^{-1}$. Compounds a3, a4, a7-a8, a18, b2-b3, and $\mathbf{c 1 - c 2}$ displayed better degrees of activity against $C$. lunaia than that of carbendazim, with $\mathbf{b} 3$ and a12 being the most effective with MIC values of $62.5 \mu \mathrm{g} \cdot \mathrm{mL}^{-1}$. Compounds a4, a7, a8, a12, a15, c1, c2, and c4 illustrated higher degrees of activity against $F$. oxysporum than that of amphotericin B, with a4 being the most effective with MIC value of $15.63 \mu \mathrm{g} \cdot \mathrm{mL}^{-1}$.

Compounds a4, a8, c1, and c2 indicated higher degrees of activity against C. lunaia and F. oxysporum than that of amphotericin B and carbendazim. Compound a7 displayed higher degrees of activity against Cytospora juglandis, C. lunaia and F. oxysporum than amphotericin B and carbendazim. Compound a8 illustrated higher degrees of activity against, C. lunaia and F. oxysporum than amphotericin B and carbendazim. Compound $\mathbf{b} 2$ manifested higher degrees of activity against V. dahliae, C. lunaia and Cytospora juglandis than amphotericin B and carbendazim. Compound b3 illustrated higher degrees of activity against $V$. dahliae, and $C$.lunaia than amphotericin $B$ and carbendazim. Especially, compound c4 displayed higher degrees of activity against $C$. orbiculare, and C. lunaia than amphotericin B and carbendazim.

\section{Materials and Methods}

\subsection{Instruments and Chemicals}

All reagents and solvents were reagent grade or purified according to standard methods before use. Analytical thin-layer chromatography (TLC) was performed with silica gel plates using silica gel 
$60 \mathrm{GF}_{254}$ (Qingdao Haiyang Chemical Co., Ltd., Qingdao, China). Melting points were measured on an Electrothermal digital apparatus (Beijing, China) and were uncorrected. The ${ }^{1} \mathrm{H}-\mathrm{NMR}(500 \mathrm{MHz})$, and ${ }^{13} \mathrm{C}-\mathrm{NMR}(125 \mathrm{MHz})$ were obtained on an AM-500 FT-NMR spectrometer (Bruker Corporation, Switzerland) with $\mathrm{CDCl}_{3}$ as the solvent and TMS as the internal standard. MS were recorded under ESI conditions using a LCQ Fleet instrument (Thermo Fisher, Waltham, MA, USA). Optical rotation was measured by an Autopol II polarimeter (Rudolph, Hackettstown, NJ, USA). Yields were not optimized. The title compounds were synthesized under a nitrogen atmosphere.

\subsection{Synthesis}

\subsubsection{Synthesis of 2-(2-Oxoindolin-3-yl)acetonitrile (2)}

To a stirred solution of indole-3-acetonitrile $(3.12 \mathrm{~g}, 20 \mathrm{mmol})$ in DMSO (30 mL) was added hydrogen chloride $\left(37 \% \mathrm{HCl}, \mathrm{V}_{\mathrm{DMSO}}: \mathrm{V}_{\mathrm{HCl}}=1: 5\right)$ dropwise at $0{ }^{\circ} \mathrm{C}$. The resulting mixture was allowed to warm to room temperature. Then the mixture was stirred for $1 \mathrm{~h}$. The solvents were removed to obtain the white solid. The solid was crystallized from acetone to provide the desired product 2 ( $3.20 \mathrm{~g}$, $93 \%$ yield).

\subsubsection{Synthesis of 2-(1,3-Dibenzyl-2-oxoindolin-3-yl)acetonitrile (3)}

To a solution of $\mathrm{NaH}(1.8 \mathrm{~g}, 75 \mathrm{mmol})$ in THF $(20 \mathrm{~mL})$ was added the compound $2(2.58 \mathrm{~g}, 15 \mathrm{mmol})$ in THF $(10 \mathrm{~mL})$ dropwise at $0{ }^{\circ} \mathrm{C}$. To the resulting mixture was added benzyl chloride $(34.5 \mathrm{mmol}$, $2.3 \mathrm{eq})$ in THF $(5 \mathrm{~mL})$ dropwise at $0{ }^{\circ} \mathrm{C}$. Then the reaction mixture was quenched with ammonium chloride $(1 \mathrm{~mL})$, and extracted three times with ethyl acetate. The organic extracts were combined, washed with brine, dried over $\mathrm{Na}_{2} \mathrm{SO}_{4}$, and concentrated. Purification by flash chromatography on silica (petroleum ether-ethyl acetate $=4: 1)$ gel afforded compound $3(3.84 \mathrm{~g}, 73 \%$ yield).

\subsubsection{Synthesis of 3a,8-Dibenzyl-1,2,3,3a,8,8a-hexahydropyrrolo[2,3-b]indole (4)}

To compound 3 ( $3.52 \mathrm{~g}, 10 \mathrm{mmol})$ in THF $(20 \mathrm{~mL})$ was added $\mathrm{LiAlH}_{4}(60 \mathrm{mmol}, 7.5 \mathrm{eq})$ at $0{ }^{\circ} \mathrm{C}$. The resulting mixture was refluxed for $2 \mathrm{~h}$, then, it was allowed to reach room temperature and stirred for another $1 \mathrm{~h}$, quenched with $\mathrm{H}_{2} \mathrm{O}(1 \mathrm{~mL})$, and extracted three times with ethyl acetate. The organic extracts were combined, washed with brine, dried over $\mathrm{Na}_{2} \mathrm{SO}_{4}$, and concentrated. Purification by flash chromatography (petroleum ether-ethyl acetate $=2: 1)$ on silica gel afforded compound $4(2.17 \mathrm{~g}$, $63 \%$ yield).

\subsubsection{Synthesis of Compounds a1-a21}

To compound 4 in pyridine $(10 \mathrm{~mL})$ was added the corresponding desired reagent at $0{ }^{\circ} \mathrm{C}$. The resulting mixture was refluxed for $2 \mathrm{~h}$. The resulting mixture was allowed to warm to room temperature and then stirred for a $1 \mathrm{~h}$. Then, the reaction mixture was quenched with methanol $(1 \mathrm{~mL})$, and extracted three times with ethyl acetate. The organic extracts were combined, washed with brine, dried over $\mathrm{Na}_{2} \mathrm{SO}_{4}$, and concentrated. Purification by flash chromatography on silica gel afforded the compounds a1-a21 in yields from 80\% to 96\%. (Characterization data see Supplementary Materials)

\subsubsection{Synthesis of 2-(1-Ethyl-1H-indol-3-yl)acetonitrile (5)}

To a solution of $\mathrm{NaH}(1.8 \mathrm{~g}, 75 \mathrm{mmol})$ in THF $(20 \mathrm{~mL})$ was added indole-3-acetonitrile ( $3.12 \mathrm{~g}$, $20 \mathrm{mmol})$ in DMSO $(30 \mathrm{~mL})$ dropwise at $0{ }^{\circ} \mathrm{C}$. The resulting mixture was allowed to reach room temperature for a further $30 \mathrm{~min}$. Then, the resulting mixture was added the compound $\mathrm{RBr}$ in THF $(5 \mathrm{~mL})$ dropwise at $0{ }^{\circ} \mathrm{C}$. The reaction mixture was quenched with ammonium chloride $(1 \mathrm{~mL})$, and extracted three times with ethyl acetate. The organic extracts were combined, washed with brine, dried over $\mathrm{Na}_{2} \mathrm{SO}_{4}$, and concentrated. Purification by flash chromatography (petroleum ether-ethyl acetate $=4: 1)$ on silica gel afforded the compound $5(1.47 \mathrm{~g}, 47 \%$ yield $)$. 


\subsubsection{Synthesis of 2-(1-Ethyl-2-oxoindolin-3-yl)acetonitrile (6)}

To a stirred solution of $5(3.12 \mathrm{~g}, 20 \mathrm{mmol})$ in DMSO $(30 \mathrm{~mL})$ was added hydrogen chloride $\left(37 \% \mathrm{HCl}, \mathrm{V}_{\mathrm{DMSO}}: \mathrm{V}_{\mathrm{HCl}}=1: 5\right)$ dropwise at $0{ }^{\circ} \mathrm{C}$. The resulting mixture was allowed to warm to room temperature and then stirred for $1 \mathrm{~h}$. Then, the solvent was removed. Purification by flash chromatography (petroleum ether-ethyl acetate $=2.5: 1)$ on silica gel afforded the compound $6(1.17 \mathrm{~g}$, $73 \%$ yield).

\subsubsection{Synthesis of 2-(1,3-Diethyl-2-oxoindolin-3-yl)acetonitrile (7)}

To a solution of $\mathrm{NaH}(1.8 \mathrm{~g}, 75 \mathrm{mmol})$ in THF $(20 \mathrm{~mL})$ was added compound 6 ( $2.58 \mathrm{~g}, 15 \mathrm{mmol})$ in THF $(10 \mathrm{~mL})$ dropwise at $0{ }^{\circ} \mathrm{C}$. The resulting mixture was added the compound RX in THF $(5 \mathrm{~mL})$ dropwise at $0{ }^{\circ} \mathrm{C}$. The reaction mixture was quenched with ammonium chloride $(1 \mathrm{~mL})$, and extracted three times with ethyl acetate. The organic extracts were combined, washed with brine, dried over $\mathrm{Na}_{2} \mathrm{SO}_{4}$, and concentrated. Purification by flash chromatography (petroleum ether-ethyl acetate = 3:1) on silica gel afforded the compound 7 (1.09 $\mathrm{g}, 82 \%$ yield).

\subsubsection{Synthesis of 3a,8-Diethyl-1,2,3,3a,8,8a-hexahydropyrrolo[2,3-b]indole (8)}

To compound $7(0.8 \mathrm{~g}, 2.8 \mathrm{mmol})$ in THF $(20 \mathrm{~mL})$ was added $\mathrm{LiAlH}_{4}(21 \mathrm{mmol}, 7.5 \mathrm{eq})$ at $0{ }^{\circ} \mathrm{C}$. The resulting mixture was refluxed for $2 \mathrm{~h}$, then allowed to warm to room temperature for a further $1 \mathrm{~h}$. Then, the reaction mixture was quenched with $\mathrm{H}_{2} \mathrm{O}(1 \mathrm{~mL})$, and extracted three times with ethyl acetate. The organic extracts were combined, washed with brine, dried over $\mathrm{Na}_{2} \mathrm{SO}_{4}$, and concentrated. Purification by flash chromatography (petroleum ether-ethyl acetate $=1.5: 1$ ) on silica gel afforded compound 8 ( $0.45 \mathrm{~g}$, 47\% yield).

\subsubsection{Synthesis of Compounds b1-c4}

To a stirred solution of compound 8 in pyridine $(10 \mathrm{~mL})$ was added the corresponding desired reagents at $0{ }^{\circ} \mathrm{C}$. The resulting mixture was heated to reflux for $2 \mathrm{~h}$. The resulting mixture was allowed to warm to rt. Then, the mixture was stirred for $1 \mathrm{~h}$. The reaction mixture was quenched with methanol $(1 \mathrm{~mL})$, and extracted three times with ethyl acetate. The organic extracts were combined, washed with brine, dried over $\mathrm{Na}_{2} \mathrm{SO}_{4}$, and concentrated. Purification by flash chromatography on silica gel afforded the compounds b1-c4 in yields, from 91\% to 94\%). (Characterization data see Supplementary Materials)

\subsection{Biological Activity}

The antimicrobial activity of calycanthaceous alkaloids analogues were measured according to the previously reported method $[29,30]$.

The tested compounds dissolved in 5\% dimethyl sulfoxide (DMSO), to a concentration of $1.02 \mathrm{mg} / \mathrm{mL}, 100 \mu \mathrm{L}$ of the solutions were added to the first well and serially diluted from first well by taking $100 \mu \mathrm{L}$ into second. This two-fold dilution was continued down the plate and $100 \mu \mathrm{L}$ from the 8th column of the plated discarded. The 9th column of the plate was reserved for negative control wells (without inocula) and the 10th column, for the positive growth control wells (without antibacterial agent). The antibacterial concentrations were $256,128,64,32,16,8,4$ and $2 \mu \mathrm{g} / \mathrm{mL}$, respectively. The antibacterial test plates were incubated aerobically at $37^{\circ} \mathrm{C}$ for $24 \mathrm{~h}$, the antifungal test plates were incubated aerobically at $28^{\circ} \mathrm{C}$ for $48 \mathrm{~h}$. The MICs, MBC and MFC were examined. MBC and MFC were determined by plating $10 \mu \mathrm{L}$ from each negative well and from the positive growth control on LB Agar and Sabouraud Dextrose Agar. MBC and MFC were defined as the lowest concentration yielding negative subcultures or only on colony. All tests were performed in triplicate and repeated if the results differed. 


\section{Conclusions}

Twenty nine novel tetrahydropyrroloindole-based calycanthaceous alkaloid derivatives were synthesized using indole-3-acetonitrile as the starting material via acylation at the N3 position, and their antimicrobial activity against nine strains of bacteria and a wide range of plant pathogen fungi were evaluated. According to the bioassay results, most of the title compounds showed moderate to excellent activities against the selected bacteria and a wide variety of plant pathogen fungi and were more effective than the positive controls. The compounds with substituted aliphatic groups at positions R4 and R5, showed higher antimicrobial activities than with the aromatic substituents. This suggested that substituents at $R_{4}$ and $R_{5}$ significantly affect the activities of title calycanthaceous alkaloid analogues. Notably, compound $\mathbf{c} 4$ displayed the broadest and most effective activities among the tested calycanthaceous analogues and might be a novel potential leading compound for further development of antifungal agents. These results will pave the way for further design, structural modification, and development of calycanthaceous alkaloids as antimicrobial agents.

Supplementary Materials: Supplementary materials can be accessed at: http://www.mdpi.com/1420-3049/21/ 9/1207/s1.

Acknowledgments: This work was supported by the National Natural Science Foundation of China (31360079, 21372185 and 21502073), the Natural Science Foundation of Jiangsu Province (Grants No BK 20150465), and Collaborative Innovation Center of Ship Technology in Jiangsu Colleges and Universities/Marine Equipment and Technology Institute for Jiangsu University of Science and Technology (HZ2016012).

Author Contributions: S.Z., H.B. and J.Z. designed research; S.Z. and S.X. performed research; X.Z. and R.Z. performed statistical analysis; S.Z. wrote the paper; H.B. and J.Z. reviewed the manuscript.

Conflicts of Interest: The authors declare no conflict of interest.

\section{References}

1. He, D.; Jian, W.; Liu, X.; Shen, H.; Song, S. Synthesis, biological evaluation, and structure-activity relationship study of novel stilbene derivatives as potential fungicidal agents. J. Agric. Food Chem. 2015, 63, 1370-1377. [CrossRef] [PubMed]

2. Lin, L.; Mulholland, N.; Wu, Q.Y.; Beattie, D.; Huang, S.W.; Irwin, D.; Clough, J.; Gu, Y.C.; Yang, G.F. Synthesis and antifungal activity of novel sclerotiorin analogues. J. Agric. Food Chem. 2012, 60, 4480-4491. [CrossRef] [PubMed]

3. Newman, D.J.; Cragg, G.M. Natural products as sources of new drugs over the last 25 years. J. Nat. Prod. 2007, 70, 461-477. [CrossRef] [PubMed]

4. Walter, M.W. Structure-based design of agrochemicals. J. Nat. Prod. 2002, 19, 278-291. [CrossRef]

5. Xiang, L.; Zhao, K.; Chen, L. Molecular cloning and expression of Chimonanthus praecox farnesyl pyrophosphate synthase gene and its possible involvement in the biosynthesis of floral volatile sesquiterpenoids. Plant Physiol. Biochem. 2010, 48, 845-850. [CrossRef] [PubMed]

6. Zhang, J.W.; Li, S.K.; Ji, Z.Q.; Hu, Z.N.; Wu, W.J. Synthesis and insecticidal activity of novel dimers of celangulin-V and podophyllotoxin. Chem. Nat. Compd. 2009, 45, 507-510.

7. Kozomara, B.; Vinterhalter, B.; Radojevic, L.; Vinterhalter, D. In vitro propagation of Chimonanthus praecox (L.), a winter flowering ornamental shrub. In Vitro Cell Dev. Biol. Plant 2008, 44, 142-147. [CrossRef]

8. Zhang, J.; Cui, L.; Li, L.; Hu, Z.; Zhang, Q.; Hu, Z.; Wu, W. Synthesis and insecticidal activities of novel nitrogenous derivatives of celangulin-V. Nat. Prod. Commun. 2014, 9, 745-748. [PubMed]

9. Liu, Y.; Liu, Y.; Xiao, H.; Gao, R.; Tian, X. Synthesis and insecticidal activities of novel derivatives of podophyllotoxin: Part XII. Pestic. Biochem. Physiol. 2008, 91, 116-121. [CrossRef]

10. Lv, J.S.; Zhang, L.L.; Chu, X.Z.; Zhou, J.F. Chemical composition, antioxidant and antimicrobial activity of the extracts of the flowers of the Chinese plant Chimonanthus praecox. Nat. Prod. Res. 2012, 26, 1363-1367. [CrossRef] [PubMed]

11. Gui, R.Y.; Liang, W.W.; Yang, S.X.; Llu, L.; Qin, J.C. Chemical composition, antifungal activity and toxicity of essential oils from the leaves of Chimonanthus praecox located at two different geographical origins. Asian J. Chem. 2014, 26, 4445-4448. 
12. Zhang, J.W.; Gao, J.M.; Xu, T.; Zhang, X.C.; Ma, Y.T.; Jarussophon, S.; Konishi, Y. Antifungal activity of alkaloids from the seeds of Chimonanthus praecox. Chem. Biodivers. 2009, 6, 838-845. [CrossRef] [PubMed]

13. Araki, T.; Manabe, Y.; Fujioka, K.; Yokoe, H.; Kanematsu, M.; Yoshida, M.; Shishido, K. Total syntheses of $( \pm)$-folicanthine and $( \pm)$-chimonanthine via a double intramolecular carbamoylketene-alkene [2+2] cycloaddition. Tetrahedron Lett. 2013, 54, 1012-1014. [CrossRef]

14. Ruiz-Sanchis, P.; Savina, S.A.; Albericio, F.; Álvarez, M. Structure, bioactivity and synthesis of natural products with hexahydropyrrolo[2,3-b]indole. Chem. Eur. J. 2011, 17, 1388-1408. [CrossRef] [PubMed]

15. Hino, T.; Yamada, S.I. Total synthesis of $( \pm$ )-folicanthine. Tetrahedron Lett. 1963, 4, 1757-1760. [CrossRef]

16. Hall, E.S.; McCapra, F.; Scott, A.I. Biogenetic-type synthesis of the calycanthaceous alkaloids. Tetrahedron 1967, 23, 4131-4141. [CrossRef]

17. Fang, C.L.; Horne, S.; Taylor, N.; Rodrigo, R. Dimerization of a 3-substituted oxindole at c-3 and its application to the synthesis of $( \pm)$-folicanthine. J. Am. Chem. Soc. 1994, 116, 9480-9486. [CrossRef]

18. Li, Y.X.; Wang, H.X.; Ali, S.; Xia, X.F.; Liang, Y.M. Iodine-mediated regioselective C2-amination of indoles and a concise total synthesis of ( \pm )-folicanthine. Chem. Commun. 2012, 48, 2343-2345. [CrossRef] [PubMed]

19. Peng, Y.; Luo, L.; Yan, C.S.; Zhang, J.J.; Wang, Y.W. Ni-catalyzed reductive homocoupling of unactivated alkyl bromides at room temperature and its synthetic application. J. Org. Chem. 2013, 78, 10960-10967. [CrossRef] [PubMed]

20. Kim, J.; Movassaghi, M. Biogenetically-inspired total synthesis of epidithiodiketopiperazines and related alkaloids. Acc. Chem. Res. 2015, 48, 1159-1171. [CrossRef] [PubMed]

21. Xu, J.B.; Cheng, K.J. Studies on the alkaloids of the Calycanthaceae and their syntheses. Molecules 2015, 20, 6715-6738. [CrossRef] [PubMed]

22. Movassaghi, M.; Schmidt, M.A. Concise Total synthesis of (-)-calycanthine, (+)-chimonanthine, and (+)-folicanthine. Angew. Chem. Int. Edit. 2007, 46, 3725-3728. [CrossRef] [PubMed]

23. Verotta, L.; Orsini, F.; Sbacchi, M.; Scheildler, M.A.; Amador, T.A.; Elisabetsky, E. Synthesis and antinociceptive activity of chimonanthines and pyrrolidinoindoline-type alkaloids. Bioorg. Med. Chem. 2002, 10, 2133-2142. [CrossRef]

24. Overman, L.E.; Paone, D.V.; Stearns, B.A. Direct Stereo- and Enantiocontrolled synthesis of vicinal stereogenic quaternary carbon centers. Total syntheses of meso- and (-)-Chimonanthine and (+)-Calycanthine. J. Am. Chem. Soc. 1999, 121, 7702-7703. [CrossRef]

25. Overman, L.E.; Paone, D.V.; Stearns, B.A. ChemInform abstract: Direct stereo and enantiocontrolled synthesis of vicinal stereogenic quaternary carbon centers. Total syntheses of meso- and (-)-Chimonanthine and (+)-Calycanthine. Cheminform 2010, 30, 6905-6919. [CrossRef]

26. Ma, M.F.; Feng, J.L.; Li, R.X.; Chen, S.W. Synthesis of Hexahypyrrole[2,3-b]indole Derivatives. CN 104250254 A, 31 December 2014.

27. Rivera-Becerril, E.; Joseph-Nathan, P.; Pérez-Álvarez, V.M.; Morales-Ríos, M.S. Synthesis and biological evaluation of (-)- and (+)-Debromoflustramine B and its analogues as selective butyrylcholinesterase inhibitors. J. Med. Chem. 2008, 51, 5271-5284. [CrossRef] [PubMed]

28. Kawasaki, T.; Ogawa, A.; Terashima, R.; Saheki, T.; Ban, N.; Sekiguchi, H.; Sakaguchi, K.; Sakamoto, M. Synthesis of diversely functionalized Hexahydropyrrolo[2,3- $b$ ]indoles using domino reactions, Olefination, isomerization and Claisen rearrangement followed by reductive cyclization. J. Org. Chem. 2005, 70, 2957-2966. [CrossRef] [PubMed]

29. Feng, N.; Ye, W.; Wu, P.; Huang, Y.; Xie, H.; Wei, X. Two New Antifungal Alkaloids Produced by Streptoverticillium morookaense. J. Antibiot. 2007, 60, 179-183. [CrossRef] [PubMed]

30. Zhang, C.; Ondeyka, J.; Guan, Z.; Dietrich, L.; Burgess, B.; Wang, J.; Singh, S.B. Isolation, structure an biological activities of platensimycin $\mathrm{B}_{4}$ from Streptomyces platensis. J. Antibiot. 2009, 62, 699-702. [CrossRef] [PubMed]

Sample Availability: Samples of the compounds are available from the authors.

(C) 2016 by the authors; licensee MDPI, Basel, Switzerland. This article is an open access article distributed under the terms and conditions of the Creative Commons Attribution (CC-BY) license (http://creativecommons.org/licenses/by/4.0/). 